\title{
EDUKACIJSKE RADIONICE KORISNIKA O NAČINIMA KORIŠTENJA INFORMACIJSKE I KOMUNIKACIJSKE TEHNOLOGIJE (2012.-2018.)
}

\author{
THE USERS' EDUCATIONAL \\ WORKSHOPS ON THE USE OF INFORMATION \\ AND COMMUNICATION TECHNOLOGY (2012-2018)
}

\author{
Slaven Pejić \\ Narodna knjižnica „Petar Preradovićc“ Bjelovar \\ slaven.pejic@knjiznica-bjelovar.hr
}

UDK / UDC 004.738.5:[027.022:374]“"2012/2018““

Stručni rad / Professional paper

Primljeno / Received: 26. 10. 2018.

Prihvaćeno / Accepted: 22. 1. 2019.

\section{Sažetak}

Cilj. Rad prikazuje edukacijske radionice o načinima korištenja informacijske i komunikacijske tehnologije organizirane za korisnike Narodne knjižnice „Petar Preradović“" Bjelovar svih dobnih skupina, održane u razdoblju od 2012. do 2018. godine. Također obrađuje problematiku uloge narodnih knjižnica u kontekstu edukacije korisnika i cjeloživotnog učenja, knjižničarske kompetencije za provođenje edukacija te informiranosti korisnika o programima koje knjižnica provodi.

Metodologija. Metodološki pristup temi ogleda se u istraživanju literature vezane uz edukacijske radionice i programe u narodnim knjižnicama, sintezi tog istraživanja, kritičkom promišljanju o temi te primjerima dobre prakse.

Rezultati. Uvidom u relevantnu stručnu i znanstvenu literaturu te kroz primjere dobre prakse provedenih radionica $\mathrm{i}$ vrednovanja njihove korisnosti iz perspektive sudionika uočeno je da narodne knjižnice mogu uspješno provoditi različite oblike neformalnog obrazovanja koji obuhvaćaju predavanja, radionice, tečajeve, okrugle stolove i sl.

Vjesnik bibliotekara Hrvatske 61, 2(2018), 381-402

ISSN 0507-1925

(C) VBH 2018. 
u suradnji sa širom lokalnom zajednicom, ustanovama i udrugama kako bi poboljšale informacijsku pismenost svojih korisnika, ali i utjecale na širi razvoj društva.

Vrijednost. Rad naglašava vrijednost neformalnog obrazovanja i cjeloživotnog učenja kako u teoriji tako i u praksi, odnosno stavlja naglasak na primjere dobre prakse koji bi trebali poslužiti kao uzor drugim knjižničarima, tj. kao smjernice za provođenje programa neformalnog obrazovanja u knjižnicama.

Ključne riječi: društvo znanja, edukacijska radionica, informacijska i komunikacijska tehnologija (ICT), kompetencije knjižničara, narodne knjižnice

\begin{abstract}
Purpose. The paper presents the educational workshops on the ways of using information and communication technologies organized in the Public library „Petar Preradović" in Bjelovar for the users of all age groups, carried out in the period from 2012 to 2018. It also addresses the issues of the role of public libraries in the context of user education and lifelong learning, as well as the competencies of librarians to carry out education and inform users on the programs implemented by the library.
\end{abstract}

Methodology. This paper topic is based on the research of the relevant professional and scientific literature that is related to educational workshops and programs for the users in public libraries, research synthesis, critical thinking, and examples of good practice.

Results. The research of the relevant professional and scientific literature and the analysis of the examples of good practice of the conducted workshops and evaluating their usefulness from the perspective of the participants, have shown that public libraries can successfully implement various forms of informal education that include lectures, workshops, courses, roundtables, etc., in cooperation with the local community, institutions, and associations in order to improve the information literacy of their users, but also to influence the wider development of society.

Value. This paper highlights the value of informal education and lifelong learning in theory and in practice, i.e. it emphasizes the examples of good practice which should serve as guidelines for implementing informal education programs in libraries.

Keywords: knowledge society, competencies of librarians, educational workshop, information and communication technology (ICT), library resources, public libraries

\title{
1. Uvod
}

Informacijsko društvo, koje se temelji na društvu znanja, postavlja nove zahtjeve pred obrazovne institucije, a knjižničari postaju informacijski stručnjaci 
koji informacije usmjeravaju prema korisnicima. Polako, ali sigurno, „tradicionalni način učenja i podučavanja zamjenjuje se novim metodama učenja baziranima na istraživačkom radu te osobu stavlja u poziciju samostalnog istraživača,

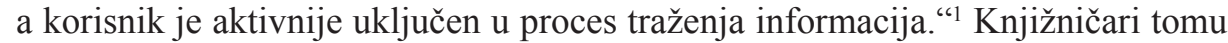
mogu gotovo svakodnevno svjedočiti u praksi, najčešće kada korisnici dolaze u knjižnicu s raznim podacima iz online knjižničnog kataloga, raspituju se o nadolazećim događanjima koja su najavljena na mrežnoj stranici knjižnice ili društvenim mrežama gdje je knjižnica zastupljena, na koje se, ako je to potrebno, i prijavljuju ili pak dolaze s općenitim informacijama koje su pronašli na internetu, a koje žele nadopuniti ili utvrditi njihovu vjerodostojnost. Također se kroz svakodnevni rad s korisnicima u Narodnoj knjižnici „Petar Preradović“ Bjelovar može primijetiti porast korisničkog traženja informacija o nekoj temi, gdje knjižničari zajedno $s$ korisnicima pretražuju knjižnični fond, dok je pak s druge strane manje traženja strogo unaprijed određene knjižnične građe. Autori Russel i Huang napominju da knjižnice u prvom redu nude zajednici svoje fondove, zatim besplatan pristup računalima s pristupom internetu, raznolikim programima i bazama podataka te također pomoć u učenju. ${ }^{2}$ Jedna od osnovnih zadaća narodne knjižnice jest potpora osobnom obrazovanju pojedinaca i skupina te se tako u zajednici razvijaju informacijske vještine i računalna pismenost. Zbog toga se u prostoru knjižnice organiziraju edukacije i radionice čiji je cilj upoznati korisnike s uslugama koje knjižnica nudi te pružiti pristupnicima radionica praktična znanja za samostalno snalaženje u svijetu u kojem sve više prevladava uporaba informacijsko-komunikacijske tehnologije. Autorica Maja Jokić u radu „Obrazovanje korisnika specijalnih i visokoškolskih knjižnica - stanje u Hrvatskoj“ navodi da se u poučavanju često zanemaruju oni koje se poučava i u biti se ne poznaju njihove prave potrebe, a upravo je to važno pri izradi obrazovnih programa. Također je potrebno definirati ciljeve poučavanja i, naposljetku, utvrditi način vrednovanja uspješnosti pouke kako bi se ona mogla unaprijediti. ${ }^{3}$ „Učinci poučavanja, oni izravni (ušteda vremena, dobivene vještine, financijska ušteda i sl.) i neizravni (percepcija knjižnice, zadovoljstvo poslom, motiviranost, mogućnost samostalnog učenja i sl.) često se u

\footnotetext{
1 Lazić-Lasić, J.; S. Špiranec; M. Banek Zorica. Izgubljeni u novim obrazovnim okruženjima - pronađeni u informacijskom opismenjavanju. // Medijska istraživanja 18, 1(2012), str. 129. [citirano 2018-10-04]. Dostupno na: http://hrcak.srce.hr/file/127116.

2 Usp. Russell, S. E.; J. Huang. Libraries' role in equalizing access to information. // Library Management 30, 1/2(2009), 69-76.

3 Usp. Jokić, M. Obrazovanje korisnika specijalnih i visokoškolskih knjižnica - stanje u Hrvatskoj. // Vloga specialnih knjižnica pri pospeševanju družbenega in gospodarskega razvoja: izobraževalni management v specialnih knjižnicah: zbornik referatov / IX. posvetovanje Sekcije za specialne knjižnice, Zveza bibliotekarskih društev Slovenije, Ljubljana, 14-15. November, 2002. Ljubljana: Narodna in univerzitetna knjižnica, 2002. Str. 107-116.
} 
praksi teško mogu izmjeriti. Neizravni se učinci također često zanemaruju, premda mogu imati dugoročniji učinak na pojedinca i ljude u njegovoj okolini.““4

U radu „Informacijsko opismenjavanje u narodnim knjižnicama“ navodi se da suradnja s lokalnom zajednicom (školama, fakultetima, obrazovnim ustanovama za odrasle, udrugama itd.) ima veliku važnost za poučavanje korisnika. Također se daje važnost ispitivanju knjižničnog okruženja i potrebe lokalnih zajednica kako bi knjižnice svoje programe mogle prilagoditi korisničkim potrebama. To često dolazi do izražaja kod narodnih knjižnica. ${ }^{5} \mathrm{U}$ ovom radu, osim teorijskog dijela vezanog uz ulogu knjižničara i knjižnica općenito u kontekstu cjeloživotnog učenja, bit će prikazan i onaj praktični, a to su edukacijske radionice održane u Narodnoj knjižnici „Petar Preradović“ Bjelovar u razdoblju od 2012. do 2018. godine, te će se pritom pokušati odgovoriti na pitanje na koji način knjižnice mogu doprinijeti cjeloživotnom učenju, poticanju pismenosti i razvitku lokalne zajednice općenito.

\section{Knjižnice i održivi razvoj}

Održivi razvoj kao pojam uveden je tek 70-ih godina prošloga stoljeća, ali se spominjao i u ranijim ekonomskim publikacijama. Potkraj 19. stoljeća, s pojavom neoklasične ekonomske teorije, pažnja se više pridaje obnovljivim resursima kao što su zrak i voda te vjetar. Ideja o održivom razvoju iznesena je kao svjetska strategija očuvanja prirodnih resursa po prvi put na Prvoj konferenciji Ujedinjenih naroda o zaštiti okoliša 1972. u Stockholmu, na kojoj je prisustvovalo 113 zemalja i oko 400 raznih drugih organizacija. ${ }^{6}$ Jedan od bitnih dijelova procesa svakako je uvođenje obrazovanja za održivi razvoj u standardno obrazovanje, čija je svrha stjecanje novih znanja u provedbi načela održivog razvoja te razvijanje samosvijesti za odgovorno ponašanje i donošenje odluka, što je u skladu s Općom deklaracijom o ljudskim pravima, odnosno o pravu na obrazovanje koje predstavlja osnovu za čovjekovo samoostvarenje i napredak. ${ }^{7}$ Osigurati pravo na obrazovanje za sve znači mogućnost obrazovanja svima bez obzira na položaj u društvu. Obrazovanje za održivi razvoj jest obrazovanje za život, odnosno za svakodnevno ponašanje i djelovanje, što uključuje stjecanje znanja, ali znanje bez vrijednosti i stavova nije dostatno. Nužno je steći proceduralna znanja i razviti spremnost za uključivanje i

\footnotetext{
4 Murphy, J.; A. Adams. Exploring the benefits of user education: a review of three case studies. // Health Information \& Libraries Journal 22, suppl. 1(2005), 45-58.

5 Usp. Stipetić Šušak, J. Informacijsko opismenjavanje u narodnim knjižnicama. // Vjesnik bibliotekara Hrvatske 59, 3-4(2016), 93-102. [citirano: 2018-06-12]. Dostupno i na: https://www. hkdrustvo.hr/vjesnik-bibliotekara-hrvatske/index.php/vbh/article/view/502/474.

6 Usp. United Nations Conference on the Human Environment (1972) [citirano 2018-12-27]. Dostupno na: https://www.encyclopedia.com/environment/energy-government-and-defensemagazines/united-nations-conference-human-environment-1972.

7 Usp. Opća deklaracija o pravima čovjeka. Dostupno na: https://www.ohchr.org/EN/UDHR/ Documents/UDHR_Translations/src1.pdf.
} 
djelovanje u skladu s vlastitim uvjerenjima i načelima. Stoga obrazovanje za održivi razvoj ne bi smjelo biti samo još jedna tema u kurikulumu koja ostaje na razini teorije, već bi ga trebalo usmjeriti na stjecanje kompetencija.

IFLA-ina Izjava o knjižnicama i razvitku naglašava upravo jedinstvenu ulogu knjižnica kao razvojnih partnera u pružanju pristupa informacijama u svim oblicima, kao i pružanje usluga i programa koji zadovoljavaju potrebe korisnika u društvu koje se ubrzano mijenja i postaje sve složenije. IFLA poziva sve sudionike u društvu da prepoznaju i priznaju knjižnice posvuda u svijetu kao pouzdane ustanove koje podupiru provedbu programa održivoga razvoja. ${ }^{8}$ Kada govorimo o održivom razvoju, valja svakako spomenuti UN-ovu Agendu 2030. UN-ova Agenda 2030 okvir je od 17 ciljeva održivog razvoja s ukupno 169 podciljeva koji obuhvaćaju gospodarski, ekološki i društveni razvoj. U posljednjih nekoliko godina IFLA je aktivno uključena u stvaranje UN-ove Agende 2030 zagovarajući uključivanje u pristup informacijama, očuvanje kulturne baštine, opće pismenosti i općenito pristupa informacijskim i komunikacijskim tehnologijama. U sadržaju programa UN-ove Agende 2030 pristup informacijama prepoznat je kao cilj u okviru održivog razvoja, odnosno cilja 16: promicanje miroljubivih i inkluzivnih društava za održivi razvoj, osiguravanje pristupa pravdi za sve i izgradnja učinkovitih, odgovornih i uključivih institucija na svim razinama. ${ }^{9}$

Knjižnice su ključne institucije za postizanje tih ciljeva, što se može vidjeti po organiziranju i oblikovanju strategije poučavanja oslanjajući se pritome najviše na informacijsku pismenost, najčešće na edukacijske radionice i programe. Autori Špiranec i Lasić-Lazić navode da

„knjižnice u svijetu uslugu edukacije korisnika temeljenu na konceptu informacijske pismenosti koriste na način podrške općih nastojanja izgradnje infrastrukture za cjeloživotno učenje." ${ }^{10}$

Informacijski pismenim osobama smatraju se one koje su naučile kako učiti samostalno i kako pronaći informacije, znaju kako je znanje organizirano i kako ga koristiti razumljiv način. Takve osobe, shodno svojim kompetencijama, mogu svoja znanja prenijeti na druge osobe koje su u procesu informacijskog opismenjavanja. Knjižnice su kao lokalna informacijska središta idealne za ispunjavanje informacijskih korisničkih potreba gdje se, osim pristupom informacijsko-komunikacijskoj tehnologiji kao pomagalu te međusobnom interakcijom knjižničara,

\footnotetext{
8 Usp. IFLA statement on libraries and development. [citirano 2018-10-18]. Dostupno na: https:// www.ifla.org/publications/ifla-statement-on-libraries-and-development.

9 Usp. Libraries, development and the United Nations 2030 Agenda. [citirano 2018-10-18]. Dostupno na: https://www.ifla.org/libraries-development.

10 Špiranec, S.; J. Lasić-Lazić. Obrazovna uloga knjižnica: priprema građana za Europu znanja. // Vjesnik bibliotekara Hrvatske 48, 1(2005), str. 29.
} 
educiranih korisnika i onih koji uče, mogu izgraditi čvrsti temelji za organizirano provođenje cjeloživotnog učenja.

U skladu s tim ciljevima, Narodna knjižnica „Petar Preradović“ Bjelovar redovitom organizacijom i provođenjem edukacijskih radionica nastoji korisnike uvesti u društvo koje uči te poučavanjem pokušava doprinijeti konceptu održivog razvoja i cjeloživotnog učenja.

\section{Kompetencije i cjeloživotno obrazovanje knjižničara}

Kako bi knjižničarska struka bila ukorak s vremenom, treba razmotriti posjeduju li knjižničari potrebne kompetencije za informacijsko opismenjavanje korisnika, koje su to uopće kompetencije i vještine te kako ih izmjeriti.

U radu Kompetencije informacijskih stručnjaka 21. stoljeća navode se četiri temeljne kompetencije, od kojih je svaka proširena specifičnim vještinama:
A. Upravljanje informacijskim organizacijama
B. Upravljanje građom
C. Upravljanje informacijskim uslugama
D. Primjena informacijskih alata i tehnologija. ${ }^{11}$

Navedene kompetencije nazivamo i stručnima jer se odnose na znanje knjižničara o građi, tehnologiji, upravljanju te sposobnosti uporabe znanja kao temelja pružanja usluga. Pregledom literature odabrane za ovaj rad možemo zaključiti da su knjižničarske kompetencije nešto što se može vrednovati i mjeriti. Autorica Mateja Paradžik u radu „Percepcija knjižničara u javnosti“ navodi kako su „kompetencije knjižničara mjerljive i mogu se razvijati i tako su proporcionalne učinkovitosti i uspješnosti u radu. “12 Shodno tomu, informacijski stručnjaci moraju ovladati suvremenom tehnologijom kako bi mogli obavljati svoju zadaću u suvremenom okruženju i znati procijeniti i odabrati uporabu najučinkovitijih informacijskih pomagala. Suvremeni knjižničar, odnosno informacijski stručnjak, trebao bi biti sposoban bez ikakvih problema primjenjivati prethodno usvojena znanja u praksi, odnosno u svakodnevnom obavljanju posla. S osobne strane, knjižničar bi trebao predstavljati osobu koja ima karakteristike prijateljski nastrojenog motivatora, koja je edukator, a ujedno i prijatelj korisnicima. Također, u radu „Kompetencije informacijskih stručnjaka 21. stoljeća" navodi se da su učinkovita i usklađena

11 Kompetencije informacijskih stručnjaka 21. stoljeća: prerađeno izdanje, lipanj 2003. [citirano 2018-10-18]. Dostupno na: http://www.nsk.hr/cuk/dokumenti/SLA\%20kompetencije.pdf.

12 Paradžik, M. Percepcija knjižničara u javnosti: završni rad. Osijek: Filozofski fakultet, 2016. [citirano 2018-23-06]. Dostupno na: https://repozitorij.ffos.hr/islandora/object/ffos\%3A619/ datastream/PDF/view. 
verbalna i neverbalna komunikacija te samostalan, ali uz to i timski rad, uzajamno poštivanje i povjerenje, planiranje karijere, stvaranje ravnoteže između poslovnog i privatnog života, slavljenje vlastitih kao i postignuća drugih, samo neke u nizu osobnih kompetencija svakog informacijskog stručnjaka ovoga vremena. ${ }^{13}$

Valja napomenuti da u stručnoj literaturi postoji više definicija cjeloživotnog učenja. Autorica Jasminka Maravić u članku objavljenom u časopisu Edupoint definira pojam cjeloživotnog učenja na sljedeći način:

„Cjeloživotno učenje definira se kao aktivnost učenja tijekom cijelog života s ciljem unapređivanja znanja, vještina i sposobnosti unutar osobne, društvene i poslovne perspektive. “"14

Ono podrazumijeva stjecanje i osuvremenjivanje svih vrsta sposobnosti, znanja i kvalifikacija kroz čitav život. U cjeloživotnom učenju sve se manje javlja formalno, a sve više neformalno obrazovanje, koje postaje okosnica koncepta cjeloživotnog učenja, ali i odgovor na izazove koje donosi moderno informacijsko doba. Cilj je usavršavanja to da pojedinac akumulira znanja i vještine koje bi mu mogle pomoći pri ostvarivanju osobnih ciljeva, a profesionalcima to da pružaju kvalitetne usluge. Isto tako, u cjeloživotno je učenje uključen i niz različitih društvenih čimbenika. Autorica Ivana Belamarić u diplomskom radu pod nazivom „Inovirani kompetencijski okvir stručnih znanja u hrvatskom knjižničarstvu“ navodi važnost konteksta koji se odnosi na organizaciju i konstantan napredak knjižničarske struke, ali i mreže podrške trajnoj izobrazbi knjižničara:

„Najprije, tu su knjižnice poslodavci, knjižničarske stručne udruge, ministarstva i druga tijela javne vlasti koja financiraju knjižnice, ali i programe izobrazbe knjižničara, zatim i sveučilišta koja organiziraju knjižničarske studije te druge ustanove/organizacije koje organiziraju neke oblike izobrazbe. “15

Iz navoda možemo zaključiti kako u proces cjeloživotnog učenja knjižnice nisu uključene kao samostalni entiteti, već su one samo jedan, iako važan, dio organiziranog sustava koji se zalaže za unapređivanje knjižničarske struke.

Međunarodna federacija knjižničarskih društava i ustanova (IFLA) prepoznala je činjenicu da se obrazovanje i učenje odvija tijekom cijelog života kroz formalno i neformalno obrazovanje, kao i informalnim učenjem, te da se navedeni načini

\footnotetext{
13 Kompetencije. Nav. dj.

14 Maravić, J. Cjeloživotno učenje. // Edupoint 3(2003), str. 34. [citirano 2018-12-06]. Dostupno i na: http://edupoint.carnet.hr/casopis/cimages/edupoint/ep_17_1.pdf.

15 Belamarić, I. Inovirani kompetencijski okvir stručnih znanja u hrvatskom knjižničarstvu: diplomski rad. Rijeka: Filozofski fakutet, 2016. [citirano 2018-12-27]. Dostupno na: https:// repository.ffri.uniri.hr/islandora/object/ffri:689/preview.
} 
učenja kontinuirano međusobno nadopunjuju. ${ }^{16}$ Knjižničar mora stvoriti poticajno okruženje za rad, osigurati dobru vidljivost usluga u knjižnici kako bi se one što lakše koristile, ostvarivati planirane sadržaje i na taj način promicati ishode učenja. Jedan od boljih načina za neformalno obrazovanje knjižničnih korisnika jest organiziranje edukacijskih radionica, gdje korisnici mogu steći znanja i vještine koje su im potrebne za zadovoljavanje informacijskih potreba, ali i za neformalno obrazovanje.

\section{Istraživanje opće informiranosti te educiranje korisnika o online uslugama Narodne knjižnice „Petar Preradovićc" Bjelovar}

Istraživanje je provedeno pomoću Anketnog upitnika (prilog 1) o korištenju online knjižničnih usluga Narodne knjižnice „Petar Preradović“ Bjelovar u prosincu 2014. godine, u kojem su tražene informacije o frekventnosti posjeta knjižnici, o vrsti najčešće korištene građe, korištenju interneta te online uslugama zasnovanim na informacijskoj tehnologiji. Pomoću anketnog upitnika ispitanici su se mogli prijaviti za sudjelovanje u edukacijama čiji bi cilj bio upoznati ih sonline knjižničnim uslugama.

Glavni cilj anketiranja bio je utvrditi stvarno stanje upućenosti korisnika u usluge koje knjižnica pruža te prijavâ za besplatne edukacije. Anketni upitnik dan je na ispunjavanje korisnicima Narodne knjižnice „Petar Preradović“ Bjelovar na Posudbenom odjelu za odrasle, Studijskom odjelu, učenicima Medicinske škole i Gimnazije u Bjelovaru te studentima Visoke tehničke škole u Bjelovaru putem elektroničke pošte.

Drugi cilj anketnog upitnika bio je utvrditi razinu poznavanja korisnika vezanu uz knjižnične usluge zasnovane na informacijskoj tehnologiji, razinu obrazovanja korisnika i to koliko često posjećuju knjižnicu, koju građu najčešće koriste, koriste li se internetom u knjižnici, pretražuju li online knjižnični katalog na mrežnim stranicama knjižnice, učestalost korištenja online znanstvene literature za učenje i pisanje radova, jesu li ikada koristili digitalne repozitorije (baze) znanstvenih i stručnih radova (Hrčak, Google Scholar, Hrvatsku znanstvenu bibliografiju), jesu li upoznati s online javnim servisima (Narodne novine, Državni zavod za statistiku i dr.), znaju li da knjižnica nudi pristup bazi EBSCO (komercijalnoj bazi podataka znanstvenih i stručnih radova), jesu li upoznati sa servisom „Pitajte knjižničare“ $i$ jesu li ga koristili te jesu li voljni sudjelovati u besplatnim edukacijama na kojima bi se upoznali s navedenim online uslugama.

Anketni upitnik ispunilo je 100 ispitanika. Najviše ispitanika ima srednjoškolsko obrazovanje (njih $50 \%$ ), visokoobrazovanih je $27 \%$, prvostupnika $21 \%$, po

16 Usp. Larsen, G. Preparing for new and changing roles in research libraries: the need for continuing professional development. // Liber Quarterly 16, 3-4(2006). DOI: http://doi. org/10.18352/lq.7863. 
jedan ispitanik posjeduje neki viši akademski stupanj, npr. magisterij ili doktorat, a jedan ima završenu osnovnu školu. Prvo pitanje odnosilo se na učestalost posjeta knjižnici, a rezultati su pokazali kako $33 \%$ ispitanika posjeti knjižnicu nekoliko puta godišnje. Jednom mjesečno knjižnicu posjećuje $28 \%$, više puta mjesečno $23 \%$, a jednom tjedno njih $16 \%$, dok učestalost posjeta ovisi o namjeni (učenje, posudba itd. ). Nadalje, $66 \%$ korisnika ne koristi internet u prostoru knjižnice preko knjižničnih računala, u odnosu na $34 \%$ onih koji koriste. Rezultati upita o korištenju online knjižničnog kataloga knjižnice pokazuju da $68 \%$ ispitanika ne koristi pristup online knjižničnom katalogu te da ga $32 \%$ ispitanika koristi. Njih $69 \%$ nije upoznato s činjenicom da knjižnica nudi pristup bazi podataka EBSCO, dok $27 \%$ kaže da je upoznato s time, no nije ju koristilo. Bazu EBSCO koristilo je $4 \%$ ispitanika, njih $50 \%$ kaže da nije upoznato sa servisom „Pitajte knjižničare“, $48 \%$ kaže da je upoznato, a svega $2 \%$ koristilo je servis. Na pitanje jesu li upoznati s online javnim servisima njih $57 \%$ odgovara da je upoznato, $32 \%$ da nije, a $11 \%$ izjasnilo se da je upoznato s navedenim servisima te ih je koristilo. Nadalje, $82 \%$ ispitanika izjasnilo se da nije voljno sudjelovati u besplatnim edukacijama, a ostatak se izjasnio pozitivno te su se isti ispitanici i prijavili na edukacije u sklopu anketnog upitnika.

\section{Edukacijske radionice korisnika o načinima korištenja informa- cijske i komunikacijske tehnologije u Narodnoj knjižnici „Petar Preradovićc' Bjelovar}

Edukacijske radionice održane su u razdoblju od 2012. do 2018. godine te je u svim radionicama naglasak bio na uporabi informacijske i komunikacijske tehnologije. Polaznici su bili članovi knjižnice svih dobnih skupina, no neke od radionica ipak su bile specijalizirane za određene skupine korisnika, ovisno o tematici radionica. Kako bi poučavanje korisnika u knjižnici bilo uspješno, valjalo je pripremiti i dobro osmisliti organizaciju radionica. Organizacija radionica važan je dio cjelokupnog koncepta edukacije korisnika jer se odražava na njihov odaziv i zadovoljstvo. Pritom je razumijevanje korisničkih potreba u kontekstu zajednice u kojoj knjižnica djeluje bitan segment za uspostavu programa i usluga potrebnih za uključivanje svih stanovnika zajednice u njezin svakodnevni život.

Planiranje radionica sastojalo se od odabira termina održavanja, osiguravanja prostora, pripreme programa i neophodne opreme. Naglasak je pritom stavljen na tehničke preduvjete za organizaciju informacijskog opismenjivanja: prostor, računalnu infrastrukturu, vrijeme te poučavatelje. Posebna je pozornost posvećena pravovremenom obavještavanju potencijalnih sudionika o održavanju radionica. Radionice su oglašavane plakatima koji su bili izloženi na glavnom ulazu u knjižnicu te na ulaznim vratima svakog odjela knjižnice posebno, ispisom i dijeljenjem brošura, objavama na društvenim mrežama te oglasima na lokalnoj radiopostaji 
Radio Terezija najmanje tjedan dana prije održavanja radionica te su korisnici zamoljeni da se prijave na radionice osobno ili putem elektroničke pošte. Kako bi organizacija radionica bila uspješna, bilo je potrebno unaprijed znati broj sudionika.

Prostor u kojem su radionice održavane bio je Studijski odjel knjižnice te iznimno Posudbeni odjel, ako je Studijski bio zauzet drugim programima, a termini održavanja radionica bili su prilagođeni korisnicima u skladu s neometanom knjižničnom djelatnošću. Valjalo je u dogovoru s ravnateljem knjižnice odrediti termine održavanja radionica kada bi se najmanje remetilo redovno knjižnično poslovanje. Termini za Studijski odjel bili su predviđeni sat vremena prije kraja radnog vremena, kada je u prostoru najmanje korisnika, dok su za Posudbeni odjel bili predviđeni u međusmjeni, kada su se edukacije održavale paralelno s knjižničnom djelatnošću.

Programi radionica uvijek su bili sadržajno temeljeni na korištenju računala, tako da se vodilo računa da, u idealnim uvjetima, svaki korisnik samostalno radi na jednom računalu. Ako je bilo više pristupnika, što je često bio slučaj, tada ih je radilo dvoje na jednom računalu. Također, korisnici su zamoljeni da, ako mogu, donesu svoja prijenosna računala, što je često rješavalo problem manjka računala za rad.

Prilikom edukacije korisnika naglasak je više stavljan na praktičan rad nego na teoriju, tako da su se izbjegavala predavanja gdje su slušatelji bili pasivni. Valja spomenuti da su sudionici nakon svake radionice dobili edukacijske materijale kako bi mogli samostalno učiti, najčešće PowerPoint-prezentaciju i zadatke za rješavanje. Također, valjalo je prilagoditi sadržaj i programe izvođenja tipu korisnika koji su se prijavili, tako da su npr. korisnici koji posjeduju osnovno ili čak napredno informatičko znanje (kao što su recimo studenti) radili na drukčiji način od onih koji takvo znanje ne posjeduju (npr. osobe treće životne dobi).

Nakon završenih radionica polaznici su bili zamoljeni da ispune Upitnik o vrednovanju uspješnosti edukacija (prilog 2) kojemu je cilj bio utvrditi odgovore na sljedeća pitanja:

- Jesu li tečajevi ispunili očekivanja polaznika?

- Jesu li polaznici zadovoljni načinom organizacije radionica (vrijeme održavanja, mjesto i dr.)?

- Smatraju li da su naučili nešto korisno ?

- Namjeravaju li u budućnosti prisustvovati radionicama/tečajevima koji će se održavati u knjižnici?

Radionice su navedene kronološkim redoslijedom održavanja jer se poslije svake radionice dolazilo do saznanja o tome što korisnici žele za temu idućih edukacijskih radionica, najčešće kroz neformalni razgovor edukatora i korisnika. 


\subsection{Radionice SOS knjižničar}

Radionice SOS knjižničar nastale su iz stvarne potrebe korisnika treće životne dobi, njihovih svakodnevnih upita kako napisati tekst na računalu, kako poslati poruku e-poštom, kako pronaći knjigu u online knjižničnom katalogu, kako se služiti internetom i sl. Nakon više upita korisnika za pomoć, pojavila se ideja o mogućnosti organiziranja radionice kojom bi se okupilo više korisnika sa sličnim zahtjevima i umjesto stalnog individualnog poučavanja organiziralo stalne skupne edukacije, što se na kraju pokazalo vrlo korisnim. Radionice su održane u razdoblju od 20. do 27. siječnja. 2013. godine te od 5. do 12. travnja. 2013. godine na Odjelu za odrasle sa sveukupno 12 polaznika. Tematski su bile previđene za osobe treće životne dobi, no bile su otvorene za sve skupine korisnika knjižnice. Program radionica sastojao se od više tema: osnove korištenja računala, osnove korištenja programa Microsoft Word, pretraživanje i evaluacija internetskih izvora te služenje online knjižničnim katalogom. Odaziv na radionice u početku nije bio najbolji, premda su bile oglašavane pomoću plakata u prostoru knjižnice, no kasnije je polaznika radionica bilo sve više, budući da su oni koji su im prisustvovali na početku preporučili radionice svojim prijateljima i poznanicima. Korisnici su uglavnom bili zadovoljni programom radionica, što su potvrdili u evaluacijskom upitniku.

\subsection{Radionice Korištenje stručnih i znanstvenih online baza podataka}

Bjelovar kao veleučilišni grad sa studijima ekonomije, sestrinstva, mehatronike i računalstva ima potrebu za znanstvenom knjižnicom. Tu ulogu preuzela je Narodna knjižnica „Petar Preradović“ budući da u svome fondu posjeduje bogate zbirke spomenutih stručnih skupina. Povećana nabava novih naslova knjiga i novina za potrebe studenata, uključujući i bazu EBSCO, na tragu je postignutih dogovora Veleučilišta u Bjelovaru i Narodne knjižnice „Petar Preradovićc“. Radionice pod nazivom Korištenje stručnih i znanstvenih online baza podataka održane su od 1. do 29. listopada. 2015. i od 2. ožujka do 13. travnja. 2016. kako bi se studentima približile knjižnične usluge za koje se smatralo da bi im koristile pri studiranju, no bile su otvorene za sve korisnike koje je zanimala ta tematika. Ukupno se prijavilo 15 polaznika. Program radionica sastojao se od poučavanja kako pretraživati i koristiti bazu podataka EBSCO, internetski pretraživač Google Scholar, efektivno pretraživanje i korištenje portala znanstvenih časopisa Hrčak, Hrvatske znanstvene bibliografije, javnih online servisa kao što su Hrvatski zavod za statistiku te vrednovanje relevantnosti informacija na webu. Radionice su bile otvorene za sve skupine korisnika, no tematski su bile rezervirane za studente i ostale korisnike s više predznanja iz informacijskih znanosti. Većina pristupnika bili su studenti i srednjoškolci te građani koji se bave znanstvenoistraživačkim radom i uglavnom su putem evaluacijskog upitnika izjavili da su zadovoljni radi- 
onicama. Na pitanje jesu li upoznati s tematikom stručnih i znanstvenih baza podataka nekoliko pristupnika odgovorilo je da do sada nisu čuli za spomenute baze podataka i servise te da smatraju da će im ova edukacija pomoći u budućnosti. Isto tako valja spomenuti da je knjižnica, kao i druge županijske knjižnice u Hrvatskoj, pretplaćena na bazu podataka EBSCO, koju korisnici redovito koriste u pisanju završnih, diplomskih, znanstvenih i sličnih radova i istraživanja.

\subsection{Radionica za roditelje: usluge E-građani i E-dnevnik}

Radionica E-dnevnik održana je 19. listopada 2017. u IV. osnovnoj školi Bjelovar s 13 prijavljenih polaznika. Polaznici su se prijavili na radionicu kod školskog knjižničara. U prvoj sesiji radionica održanoj u IV. osnovnoj školi polaznici su bili isključivo roditelji. Neki od njih čuli su za navedene usluge i bili su s njima upoznati. Također, neki su od polaznika imali poteškoća s korištenjem sustava $E$-dnevnik. Mrežna aplikacija E-dnevnik uspostavljena je školske godine 2011./2012. radi vođenja razredne knjige u elektroničkom obliku. Aplikaciju je izradio CARNET, a odlikuje se svim funkcionalnostima postojeće razredne knjige, uz dodatne funkcionalnosti koje pruža uporaba informacijsko-komunikacijskih tehnologija. E-dnevnik trenutno koristi više od 1160 škola u Hrvatskoj. Aplikacija E-dnevnik i učenicima olakšava praćenje obaveza i dosadašnjeg uspjeha u nastavnoj godini, dakle pregled ocjena, bilješki, izostanaka, lektira i rasporeda pisanih zadaća koje su nastavnici unijeli u E-dnevnik. Učenici se u aplikaciju prijavljuju svojim AAI@Edu. $h r$ korisničkim identitetom koji dobivaju od administratora imenika svojih škola. Također, razvijena je i aplikacija E-dnevnik za roditelje pomoću koje roditelji učenika dobivaju mogućnost uvida u ocjene i izostanke svoje djece. Pristup aplikaciji za roditelje omogućen je korisnicima koji su registrirani u sustavu E-građani. ${ }^{17} \mathrm{Po}$ završetku radionice proveden je evaluacijski upitnik te su pristupnici izjavili da im je radionica koristila i da u budućnosti planiraju sudjelovati u sličnim radionicama edukacijske naravi.

Druga radionica na temu sustava E-građani održana je u prostoru Studijskog odjela knjižnice u vremenu od 12. do 19. prosinca 2017. Sustav E-građani jest projekt digitalizacije javne uprave koji je modernizirao, pojednostavio i ubrzao komunikaciju s građanima, smanjio potrebu za čekanjem u redovima te povećao transparentnost javnog sektora u pružanju usluga građanima. Uslugama u sustavu E-građani i Osobnom korisničkom pretincu mogu pristupiti svi građani Republike Hrvatske stariji od 15 godina. Neke od usluga uključuju: elektroničke izvode iz matične knjige rođenih, vjenčanih ili knjige državljana, provjeru podataka u Registru birača, preglede elektroničkih zapisa, a potom i ispisa uvjerenja o prebivalištu, boravištu te vlasništvu cestovnih vozila, zahtjev za vlastitom elektroničkom radnom knjižicom, informacije o očekivanom iznosu mirovine, registraciju

17 Usp. E-Dnevnik. [citirano 2018-10-04]. Dostupno na: https://www.carnet.hr/e-dnevnik. 
kao potencijalnog posloprimca, provjeru podataka u sustavu OIB-a, pretraživanje osnovnih katastarskih podataka i podnošenje zahtjeva za izdavanje javnih isprava i rješenja u katastarskim uredima. ${ }^{18}$ Radionici je prisustvovalo 12 polaznika, a bila je otvorena za sve članove knjižnice. Korisnici su o radionicama obaviješteni putem mrežne stranice knjižnice, Facebook-stranice knjižnice te prigodnim letcima.

\subsection{Radionice Osnove informatike za mlade mame}

Radionice Osnove informatike za mlade mame organizirane su u suradnji s Dječjim odjelom Narodne knjižnice „Petar Preradović“, gdje su od 7. veljače do 28. ožujka 2012. i provedene sa sveukupno 9 sudionica. Program radionica bio je predviđen za majke djece koja su članovi Dječjeg odjela knjižnice te je uključivao upoznavanje sudionika s paketom programa MS Office (MS Word, MS Excel, MS PowerPoint), pretraživanje i vrednovanje informacija na internetu, osnovno i napredno korištenje elektroničke pošte. Sudionice su se pozitivno izjasnile o programu i organizaciji radionica i većina ih je odgovorila da smatraju da su naučile nešto novo i korisno. Također, izrazile su želju da ih se putem elektroničke pošte obavijesti kada će se organizirati radionice sa sličnom tematikom budući da zbog nedostatka slobodnog vremena nisu u mogućnosti samostalno učiti.

\subsection{Radionice Upoznavanje i korištenje uređaja Micro:bit}

Micro:bitovi su edukacijska mikroračunala namijenjena prvenstveno djeci, koja pomoću njih vrlo jednostavno mogu usvajati osnove programiranja, elektrotehnike te digitalne pismenosti općenito. Jednostavnim naredbama izvedenim iz grafičkog programskog jezika djeca, ali i svi ostali, vrlo brzo mogu usvojiti osnove programiranja i programskog razmišljanja.$^{19}$ Radionice su održane 5. svibnja 2018. u prostoru Dječjeg odjela Narodne knjižnice „Petar Preradović“" Bjelovar s 12 polaznika, 1. lipnja 2018. godine u Osnovnoj školi Štefanje s 14 polaznika te 13. lipnja 2018. u Područnoj školi „Mirka Pereša“ u Starim Skucanima s 18 polaznika. Sveukupno su na radionicama prisustvovala 44 polaznika. Program radionica obuhvaćao je korištenje Micro:bit-uređaja te programiranje uređaja pomoću simulatora. Pristupnici radionica bili su isključivo učenici navedenih škola. Neki od njih dosad su bili upoznati s Micro:bit-uređajima, dok većina ipak nije. Shodno tomu, valjalo je izdvojiti dosta vremena za upoznavanje djece s uređajima budući da se oni moraju pripremiti te spojiti na računalo. Polaznici edukacija bili su veći-

\footnotetext{
18 Usp. E-Građani: kako se prijaviti. [citirano 2018-10-04]. Dostupno na: https://www.ucionica. net/internet/e-gradani-kako-se-prijaviti-4271/.

19 Usp. Jeste li već posudili micro:bit iz knjižnice? [citirano 2018-10-04]. Dostupno na: http:// velikagorica.com/vijesti/kronikevg-56158.
} 
nom učenici koji su s oduševljenjem prihvatili edukaciju, a mnogi od njih izrazili su želju za samostalnim korištenjem uređaja. Knjižnica u svom fondu posjeduje dovoljan broj Micro:bit-uređaja koje daje na posudbu korisnicima za samostalan rad.

\subsection{D-ispis u Narodnoj knjižnici „Petar Preradović“ Bjelovar}

U modernim vremenima, traganje za novim tehnologijama i rješenjima koja se mogu upotrijebiti za boljitak čovječanstva događa se svaki dan. 3D-pisač samo je jedan u nizu izuma koje možemo smatrati rezultatom tog traganja. „Prvi 3D-pisač izumljen je 1981. godine na Institutu za industrijsko istraživanje u Japanu. Današnji 3D-pisači koriste se u izradi nekih vrlo preciznih industrijskih i komercijalnih dijelova. Sve se više ulaže u razvoj i poboljšavanje 3D-pisača zbog toga što su jeftini, izrađeni modeli veoma su kvalitetni te se mnogo koriste u industriji.“20 $\mathrm{Na}$ internetu postoji mnoštvo stranica s kojih je moguće preuzeti gotove modele te ih samo „ubaciti“ u program za kontroliranje 3D-pisača i ispisati. Nacionalna i sveučilišna knjižnica u Zagrebu i Institut za razvoj i inovativnost mladih potpisali su u travnju 2018. godine sporazum o suradnji radi poticanja primjene novih tehnologija u knjižnicama u Republici Hrvatskoj. Raspisan je natječaj za donaciju 3D-pisača na koji se Narodna knjižnica „Petar Preradović“ Bjelovar prijavila i dobila uređaj - model Prusa i3 MKS2. Zaposlenici knjižnice prisustvovali su edukaciji za korištenje 3D-pisača u Nacionalnoj i sveučilišnoj knjižnici u Zagrebu. 3D ispis u knjižnici nova je usluga koja se planira implementirati u budućnosti. Upoznavanje s uređajem i prezentacija korištenja 3D-pisača planira se održati na Studijskom odjelu Knjižnice. Pritom se planiraju organizirati edukacijske radionice čija bi tematika bila upoznavanje korisnika s 3D-pisačem te njegovo funkcionalno korištenje.

\section{Zaključak}

Poučavanje korisnika obogaćuje ponudu knjižnice, a time utječe i na stvaranje kvalitetnijeg društvenog okruženja. Prikazani primjeri dobre prakse edukacije korisnika knjižnice svakako su kvalitetan iskorak u radu same knjižnice jer na taj način knjižnica korisnike na jednostavan, brz i intenzivan način u kratkom vremenu poučava i omogućuje im da samostalno pronalaze relevantne izvore informacija te kvalitetnije koriste knjižnične usluge. Narodne knjižice mogu provoditi različite

20 Uršulin, Ž. Izrada i testiranje modela 3D pisača baziranoga na Arduino platformi: završni rad. Varaždin: Sveučilište Sjever, 2015. [citirano 2018-12-06]. Dostupno na: https://repozitorij.unin. $\mathrm{hr} /$ islandora/object/unin:141/preview. 
oblike neformalnog obrazovanja koji obuhvaćaju predavanja, radionice, tečajeve, okrugle stolove i sl., u suradnji sa širom lokalnom zajednicom, ustanovama i udrugama, kako bi poboljšale informacijsku pismenost svojih korisnika, ali i utjecale na širi razvoj društva, posebice održivi razvoj. Kako bi se postigla potpuna učinkovitost, potrebno je korisnicima ukazati na važnost knjižnica, ali i naučiti ih kako u knjižnici mogu učiti. Knjižničar ima ključno mjesto kada je riječ o cjeloživotnom učenju u knjižnicama. Osim posudbe knjižnične građe te ostalih temeljnih knjižničnih djelatnosti, on je ujedno i edukator koji ima ulogu naučiti korisnika kako koristiti izvore te kako koristiti tehnike pretraživanja i brže doći do željene informacije. Nažalost, često se u praksi događa da se korisniku samo osigurava pristup informaciji, a ostale se stupnjeve opismenjavanja zanemaruje. Profesionalne vještine knjižničara stječu se programom obrazovanja svakoga knjižničara te su, kao i osobne vještine, bitne u prijenosu znanja korisnicima. Također, knjižničarima stručni radovi uvelike mogu pomoći u stvaranju okvirne slike o tome koje bi kompetencije knjižničar trebao imati kako bi se uključio u proces cjeloživotnog učenja korisnika. Edukacijske programe knjižničar može obavljati na određenoj razini koja često ovisi o njegovoj osobnoj motivaciji, osobnim i stručnim kompetencijama. Stručna literatura može dati smjernice za standardizaciju u budućem radu te knjižničari mogu planirati buduće strukturirane korake s obzirom na znanje i kontekst u kojem se nalaze.

Provedene edukacijske radionice opisane u ovom radu primjeri su dobre prakse i jedan od načina na koje knjižničar može iskoristiti svoje kompetencije za dobrobit korisnika. To znači iskoristiti informacijsku pismenost kako bi mogao provesti radionice te ih organizirati i osmisliti vlastitom kreativnošću i energijom, $\mathrm{a}$ istovremeno se stalno usavršavati održavajući korak s modernim trendovima, $\mathrm{i}$ to prisustvovanjem na stručnim skupovima, praćenjem novosti iz svijeta knjižničarstva i dr. Radionice predstavljene u radu bile su tematski vezane uz korištenje informacijske i komunikacijske tehnologije svih dobnih skupina korisnika Narodne knjižnice „Petar Preradović“ Bjelovar, a održane su u razdoblju od 2012. do 2018. godine i sve su za cilj imale edukaciju korisnika u korištenju informacijskih tehnologija kako bi zadovoljili svoje informacijske potrebe, ali i naučili kako učiti samostalno, što je jedan od ciljeva cjeloživotnog učenja. Osim samog prikaza radionica, jedan od ciljeva svakako je bio ukazati na mjesto i ulogu knjižnice u suvremenom društvu. Planiranje i modeli organizacije radionica u suradnji sa školama i odjelima Knjižnice, timski rad u provedbi, oglašavanje kao oblik marketinga i druge tehničke pojedinosti, sve do povratnih informacija dobivenih od polaznika o korisnosti i primjenjivosti usvojenih znanja, samo su jedan od segmenata moderne knjižnične djelatnosti koja, u skladu s načelima održivog razvoja, sudjeluje u kreiranju bolje budućnosti lokalne zajednice, ali i šire. 


\section{LITERATURA}

Belamarić, I. Inovirani kompetencijski okvir stručnih znanja u hrvatskom knjižničarstvu: diplomski rad. Rijeka: Filozofski fakutet, 2016. [citirano 2018-12-27]. Dostupno na: https://repository.ffri.uniri.hr/islandora/object/ffri:689/preview.

E-Dnevnik. [citirano 2018-10-04]. Dostupno na: https://www.carnet.hr/e-dnevnik.

E-Građani: kako se prijaviti. [citirano 2018-10-04]. Dostupno na: https://www.ucionica. net/internet/e-gradani-kako-se-prijaviti-4271/.

IFLA statement on libraries and development. [citirano 2018-10-18] Dostupno na: https://www.ifla.org/publications/ifla-statement-on-libraries-and-development.

Jeste li već posudili micro:bit iz knjižnice? [citirano 2018-10-04]. Dostupno na: http:// velikagorica.com/vijesti/kronikevg-56158.

Jokić, M. Obrazovanje korisnika specijalnih i visokoškolskih knjižnica - stanje u Hrvatskoj. // Vloga specialnih knjižnica pri pospeševanju družbenega in gospodarskega razvoja: izobraževalni management $\mathrm{v}$ specialnih knjižnicah: zbornik referatov / IX. posvetovanje Sekcije za specialne knjižnice, Zveza bibliotekarskih društev Slovenije, Ljubljana, 14-15. November, 2002. Ljubljana: Narodna in univerzitetna knjižnica, 2002. 107-116.

Kompetencije informacijskih stručnjaka 21. stoljeća: prerađeno izdanje, lipanj 2003. [citirano 2018-10-18]. Dostupno na: http://www.nsk.hr/cuk/dokumenti/SLA\%20 kompetencije.pdf.

Larsen, G. Preparing for new and changing roles in research libraries: the need for continuing professional development. // Liber Quarterly 16, 3-4(2006). DOI: http://doi. org/10.18352/lq.7863.

Lazić-Lasić, J.; S. Špiranec; M. Banek Zorica. Izgubljeni u novim obrazovnim okruženjima - prona-đeni u informacijskom opismenjavanju. // Medijska istraživanja 18, 1(2012), 125-142. [citirano 2018-10-04]. Dostupno i na: http://hrcak.srce.hr/ file/127116.

Libraries, development and the United Nations 2030 Agenda. [citirano 2018-10-18]. Dostupno na: https://www.ifla.org/libraries-development.

Maravić, J. Cjeloživotno učenje. // Edupoint, 3(2003), 34-38. [citirano 2018-12-06]. Dostupno i na: http://edupoint.carnet.hr/casopis/cimages/edupoint/ep_17_1.pdf.

Murphy, J.; A. Adams. Exploring the benefits of user education: a review of three case studies. // Health Information \& Libraries Journal 22, suppl. 1(2005), 45-58.

Opća deklaracija o pravima čovjeka. [citirano 2018-10-18]. Dostupno na: https://www. ohchr.org /EN/UDHR/Documents/UDHR_Translations/src1.pdf.

Paradžik, M. Percepcija knjižničara u javnosti: završni rad. Osijek: Filozofski fakultet, 2016. [citirano 2018-23-06]. Dostupno na: https://repozitorij.ffos.hr/islandora/obje$\mathrm{ct} / \mathrm{ffos} \% 3 \mathrm{~A} 619 /$ datastream/PDF/view. 
Russell, S. E.; J. Huang. Libraries' role in equalizing access to information. // Library Management 30, 1/2(2009), 69-76.

Stipetić Šušak, J. Informacijsko opismenjavanje u narodnim knjižnicama. // Vjesnik bibliotekara Hrvatske 59, 3-4(2016), 93-102. [citirano: 2018-06-12]. Dostupno i na: https://www.hkdrustvo.hr/ vjesnik-bibliotekara-hrvatske/index.php/vbh/article/ view/502/474.

Špiranec, S.; J. Lasić-Lazić. Obrazovna uloga knjižnica: priprema građana za Europu znanja. // Vjesnik bibliotekara Hrvatske 48, 1(2005), 46-56.

United Nations Conference on the Human Environment (1972) [citirano 2018-1227]. Dostupno na: https://www.encyclopedia.com/environment/energy-government-and-defense-magazines/united-nations-conference-human-environment-1972.

Uršulin, Ž. Izrada i testiranje modela 3D pisača baziranoga na Arduino platformi: završni rad. Varaždin: Sveučilište Sjever, 2015. [citirano 2018-12-06]. Dostupno na: https://repozitorij.unin.hr/islandora/object/unin:141/preview. 


\section{PRILOG 1.}

\section{ANKETNI UPITNIK O KORIŠTENJU ONLINE KNJIŽNIČNIH USLUGA NARODNE KNJIŽNICE „PETAR PRERADOVIĆ“ BJELOVAR}

Ova se anketa provodi radi stjecanja informacija o zadovoljstvu i preferencijama korisnika te kako bismo sukladno tomu mogli uvesti nove usluge i poboljšati postojeće.

Anketa je u potpunosti anonimnog karaktera. Zahvaljujemo Vam na vremenu koje ćete odvojiti za ispunjavanje ove ankete.

Molimo Vas da vratite popunjenu anketu na informacijski pult knjižnice ako ju ispunjavate $u$ našim prostorijama. Ako anketu popunjavate putem elektroničke pošte, molimo Vas da ju vratite e-poštom na adresu pošiljatelja. Vaši će nam odgovori uvelike pomoći pri unapređivanju naših usluga.

Molimo Vas da upišete svoje godište kraj oznake Vašega stupnja naobrazbe:
a) osnovno obrazovanje
b) srednje obrazovanje
d) visoko obrazovanje
e) akademski stupanj

\section{Koliko često posjećujete Knjižnicu?}

jednom tjedno

jednom mjesečno

dvaput mjesečno

svakih nekoliko mjeseci

svakodnevno

\section{Koju građu najčešće koristite? (više odgovora)}

stručne publikacije (knjige, zbornike)

rječnike, leksikone, enciklopedije

elektroničku građu (CD, DVD)

novine i časopise

online baze podataka znanstvenih i stručnih članaka

Ostalo 
3. Pristupate li internetu u Knjižnici?

DA

NE

POVREMENO

4. Pretražujete li E-katalog na mrežnim stranicama Knjižnice?

DA

NE

POVREMENO

5. Koliko često koristite znanstvenu literaturu za učenje ili pisanje radova dostupnu online?

NIKADA

PONEKAD

ČESTO

UVIJEK

6. Jeste li ikada koristili digitalne repozitorije (baze) znanstvenih i stručnih radova (Hrčak, Google scholar, Hrvatsku znanstvenu bibliografiju i dr.)? NIKADA

PONEKAD

ČESTO

UVIJEK

7. Znate li da Knjižnica nudi pristup bazi EBSCO (komercijalnoj bazi podataka, znanstvenih i stručnih radova)?

DA

NE

DA I KORISTIO/LA SAM BAZU

8. Jeste li upoznati sa servisom „Pitajte knjižničare“?

DA

NE

DA I KORISTIO/LA SAM SERVIS 
10. Jeste li upoznati s online javnim servisima i uslugama (Narodne novine, Državni zavod za statistiku, E-građanin)?

DA

NE

DA I KORISTIO/LA SAM SERVIS

11. Jeste li voljni sudjelovati u besplatnim edukacijama na kojima biste se educirali kako koristiti online usluge i servise navedene u ovoj anketi?

DA

NE

12. Ako planirate sudjelovati na radionicama koje će se održavati u prostoru Studijskog odjela Knjižnice, molimo Vas da upišete svoju adresu e-pošte kako bismo Vas obavijestili o mjestu i vremenu održavanja edukacija.

ZAHVALJUJEMO NA SUDJELOVANJU U OVOJ ANKETI! 


\section{PRILOG 2.}

\section{ANKETNI UPITNIK O VREDNOVANJU USPJEŠNOSTI EDUKACIJA U NARODNOJ KNJIŽNICI „PETAR PRERADOVIĆ“ BJELOVAR}

Molimo Vas da popunite ovu anketu kako bismo mogli unaprijediti kvalitetu budućih edukacija!

Molimo, zaokružite odgovor:

Spol

$\mathrm{M}$

$\check{Z}$

1.Jesu li provedene edukacije ispunile sva vaša očekivanja?
Očekivao/la sam više
$\square$ Očekivano
$\square$ Više od očekivanog

2. Jeste li zadovoljni načinom organizacije (vrijeme održavanja, mjesto...)?

$\square$ Nisam zadovoljan/a $\quad \square$ Zadovoljan/a sam $\quad \square$ Oduševljen/a sam

3. Smatrate li da ste naučili nešto korisno na održanim edukacijama?

$\square$ Nisam naučio/la ništa novo $\square$ Vjerojatno sam naučio/la nešto novo

$\square$ Naučio/la sam nešto novo

4. Namjeravate li u budućnosti prisustvovati edukacijama koji će se održavati u Knjižnici?
$\square$ Ne, nikada
Možda
Sigurno

PRIJEDLOZI / KRITIKE / POHVALE 
Molimo popunite ovu anketu kako bi u budućnosti mogli unaprijediti provođenje knjižničnih edukacija

Zaokružite odgovor:

$\mathrm{M}$

$\check{Z}$

2. Jesu li tečajevi ispunili sva vaša očekivanja?

$\square$ Očekivao/la

Očekivano

Više od

Puno više od sam više očekivanog očekivanog

3. Jeste li zadovoljni načinom organizacije (vrijeme održavanja, mjesto...)

$\square$ Nisam

Zadovoljan/a zadovoljan/a

Više nego

Oduševljen/a zadovoljn/a

4. Smatrate li da ste naučili nešto korisno na održanim tečajevima?

Nisam naučio/ Vjerojatno sam Naučio/la sam la ništa novo naučio/la nešto nešto novo novo

5. Namjeravate li u budućnosti prisustvovati tečajevima koji će se održavati u knjižnici?
Ne, nikada
Možda
Sigurno

PRIJEDLOZI / KRITIKE / POHVALE : 